Yale University received the Harcourt College Publishers Award for his article, "Decision Making in a Democracy: The Supreme Court as a National Policy Maker" (Journal of Public Law 6: 279-95 [1958]). The award is given for a book or journal article 10 years or older that has made a lasting impression on the field of law and courts. The Congressional Quarterly Press Award, conferred for the best graduate student paper presented during 1999 , was given to Michael Ebeid of Yale University for "Do Presidents Shape Supreme Court Ideology? An Analysis of Judicial Agreement Tendencies." Harold J. Spaeth of Michigan State University and Jeffrey A. Segal of the University of Kansas were awarded the C. Herman Pritchett Award for Majority Rule or Minority Will: Adherence to Precedent on the U.S. Supreme Court (Cambridge University Press, 1999). The Pritchett Award was given for the best book on law and courts written by a political scientist and published in 1999. Honorable Mention was given to Judith A. Baer of Texas A\&M University for Our Lives Before the Law: Constructing a Feminist Jurisprudence (Princeton University Press, 1999). Lastly, the Lifetime Achievement Award honoring a distinguished career of achievement and service in the field of law and courts was given to Beverly Blair Cook, who is professor emeritus at University of Wisconsin, Milwaukee.

\section{Legislative Studies}

At the Legislative Studies business meeting, the section presented a number of prizes. The CQ Press Award for the best paper on legislative studies presented at the 1999 APSA Annual Meeting went to David Brady, Kara Buckley, and Doug Rivers of Stanford University for their paper, "Strong Parties Revisited, 1870-1930." The Carl Albert Dissertation Award for the best doctoral dissertation in the area of legislative studies (1997-98) was given to Glen S. Krutz of Arizona State University for "Explaining Institutional Change: The Rise and Impact of Omnibus Legislating." And David Canon of the University of Wiscon-

\section{Washington Insider}

\section{Priorities of NEH Questioned by Scholars}

Since surviving a threat of elimination in 1996, the National Endowment for the Humanities has struggled to meet scholar's demands for support of academic projects and Congress' demands for developing popular programs. Of special concern to historians and linguists is the Endowment's decreasing support for long-term projects, like editing the papers of Susan B. Anthony and compiling a Sumerian dictionary, and increasing support for strictly popular projects like a photography exhibit titled "Barn Again."

Agency director Willaim Ferris has defended the reallocation of funds as necessary to ensure the NEH's survival. He has also said that winning Congressional support for any NEHsponsored projects would help increase funds for all projects. His argument was partially borne out this year when Congress approved a $\$ 5$ million increase in the FY01 Endowment budget, the first significant increase in five years. Still, many questions whether NEH is meeting the needs of its core constituency.

A draft of a policy statement on supporting long-term projects has been posted for comment at www.neh.gov/news/editionssupport.html. Currently, NEH funds 62 long-term projects.

\section{Females Match or Exceed Males in Educational Attainment}

A recent national survey of educational attainment revealed that females have caught up with or surpassed males in nearly all categories. Female students consistently outperform their male peers in reading and writing, young men and women take equally challenging math and science courses in high school, and females are more likely than males to both enroll in and complete college. More information can be found in Trends in Educational Equity of Girls and Women, which is available from the National Center for Education Statistics.

\section{Majority of Graduate Students Part Time}

As reported in Lifelong Learning Trends, just over half of all U.S. graduate students attended school part time during the 1995-96 school year and a large majority of all individuals seeking graduate degrees were enrolled in master's or first professional programs. The University Continuing Education Association, which compiled the report, also found that 57\% of master's degree recipients in 1997 were women. More information is available on the UCEA web site (www.nucea.edu).

\section{Too Many Ph.D.s?}

In Addressing the Nation's Changing Needs for Biomedical and Behavioral Scientists, a committee of the National Research Council recommended that "there should be no growth in the aggregate number of Ph.D.s awarded in the behavioral and social sciences." In light of the current and projects needs, the committee concluded that "the present number of approximately 2600 new behavioral and social science Ph.D.s a year is sufficient . . . until at least 2005.

Women Hold Increasing Share of Faculty Positions while Minorities' Shares Hold Steady

In 1997, women held $41 \%$ of the 989,813 faculty positions available at the 4093 U.S. colleges and universities that participated in federal student loan programs. This share is up from $27 \%$ in 1976. The news is only slightly encouraging, though, because women are overrepresented among the ranks of part-time faculty. Also less than encouraging for champions of diversity, blacks held only $5 \%$ of faculty positions, while Latinos held $2.6 \%$, Asians $3 \%$, and Native Americans $0.2 \%$. Full details can be found in Fall Staff in Postsecondary Institutions, 1997 (available at www.nces.ed.gov/pubsearch).

\section{Follow Ups}

- A bill Senator Daniel Moynihan (D-NY) introduced in 1999 in the hopes of transforming the federal government's information classification system was attached to a much-modified version as a rider to the FY2001 Intelligence Authorization Act. The Public Interest Declassification Act (S. 1801) calls for creation of nine-member board charged with promoting openness, supporting congressional oversight of decalssification, and making recommendations to the president on classification policies and practices.

- Rep, Dan Miller (R-FL), chair of the House Subcommittee on the Census, has introduced legislation that would establish a 10-year fixed term for the director of the U.S. Census Bureau. According to Miller the bill would help remove partisan politics from the census and "allow one director to supervise an entire census from planning to implementation."

Information for this colum was taken from the Chronicle of Higher Education; Comments, a bimonthly publication of the Commission on Professionals in Science and Technology; the Consortium's of Social Science Associations's Washington Update; and the NCC Washington Update (www.h-net.msu/ ncc.) 